\title{
Alternative food shoppers and the "quantity dilemma": a study on the determinants of their purchases at alternative markets
}

\author{
Clara Cicatiello(1)
}

Correspondence: cicatiello@unitus.it Department for Innovation in Biological, Agro-food and Forest Systems, University of Tuscia, via San Camillo de Lellis snc, 01100 Viterbo, Italy

\begin{abstract}
Despite the increasing interest around alternative food networks and their huge growth in the last decades, they are still considered a complementary source of provision by most customers. Alternative food shoppers are faced with a "quantity dilemma", i.e., choosing how much food they want to buy through these channels. This decision affects the importance of alternative food networks in the market and the extent to which they may contribute to the improvement of the food systems' overall sustainability. Basing on a survey involving 1200 food shoppers interviewed at alternative markets in Italy, this paper studies the factors explaining the quantity of food that customers choose to buy there, with respect to the quantity they purchase through conventional channels. Results show that their motivations to buy at alternative markets are crucial to increase the share of food provisions attained through these channels, especially when quality and environmental motivations are concerned. Another key factor is the type of alternative market where consumers are used to shop at, with box schemes being more likely to represent a main source of food provision for their customers than farmers' markets and farm shops. A strong effect is played by customers' loyalty to alternative markets, showing that establishing a long-term relation with producers participating at alternative markets increases the probability of buying more food through these channels. These findings disclose a potential in terms of upscaling of alternative food networks, linked to the identification of the consumers segments that are more likely to use these channels as a main source of food provision, and to the types of business models that can more likely increase the quantity of food purchased.
\end{abstract}

Keywords: Alternative food networks, Local food systems, Short food supply chain, Local food, Farmers' market, Food purchase, Consumer behavior, Logistic regression

\section{Introduction}

The industrialization of the global food supply chains, which occurred in the past decades, has raised several concerns over the sustainability of our food systems (Aggestam et al. 2017), calling for a transition (Hinrichs 2014) to be supported at different levels of the production

(c) The Author(s). 2020 Open Access This article is licensed under a Creative Commons Attribution 4.0 International License, which permits use, sharing, adaptation, distribution and reproduction in any medium or format, as long as you give appropriate credit to the original author(s) and the source, provide a link to the Creative Commons licence, and indicate if changes were made. The images or other third party material in this article are included in the article's Creative Commons licence, unless indicated otherwise in a credit line to the material. If material is not included in the article's Creative Commons licence and your intended use is not permitted by statutory regulation or exceeds the permitted use, you will need to obtain permission directly from the copyright holder. To view a copy of this licence, visit http://creativecommons.org/licenses/by/4.0/. 
and consumption processes. As a reaction to these challenges, many food chain actors have started to join alternative production and consumption patterns, grounded on the relocalization of the food systems (Kneafsey et al. 2013) that may result in a greater sustainability of the food chains. Biodiversity conservation, farmers' value added, and the strong relation with the territory have been indicated as the most relevant sustainability attributes of local food chains (Galli et al. 2015).

This situation facilitated the development of alternative food networks (AFNs) arising in contrast with mainstream distribution channels based on large-scale production and standardization (Renting et al. 2003; Higgins et al. 2008). Their distinctive feature is the geographic and/or relational proximity of production and consumption processes (Aubry and Kebir 2013; Pascucci et al. 2011); to recall, the local origin of products and/ or the low number of intermediaries along the chain are also elements of short food supply chains (Marsden et al. 2000). Examples of AFNs include farm shops, farmers' markets, producers' shops, pick-your-own farms, box schemes, solidarity purchasing groups, and community-supported agriculture.

The development of AFNs was initially pushed by farmers as a market strategy to prevent the "squeezing" between upstream and downstream chain actors (Van Der Ploeg 2010) and to overcome the asymmetry in farm-to-retail markets (Xia 2009), thus increasing the profitability of farming activities and their market power. However, their success is strictly connected to the changing demand of consumers, that in the same years turned to a higher attention to quality (Goodman 2003) and a greater awareness of the environmental and social issues linked to mainstream food systems (Ilbery and Maye 2005).

The growth of AFNs has been very fast both in the USA and in Europe. In the USA, the number of farmers' markets grew from 1755 in 1994 to 8717 in 2018, becoming a widespread phenomenon in most of the USA ${ }^{1}$. In Europe, the diffusion of AFNs is more recent, and the UK is the country where they have encountered the greatest success. Following the first farmers' market which opened in Bath in 1997 (Kirwan 2006), in 2009, FARMA ${ }^{2}$ counted 750 markets. In Italy, Coldiretti ${ }^{3}$ counted over 1000 operating farmers' markets in 2013. More innovative examples of alternative markets are also spreading all around the world: community-supported agriculture schemes are now operating in over 25 different countries (http://www.urgenci.net), while solidarity purchasing groups are particularly developed in Italy (Franco et al. 2015), where Cembalo et al. (2013) reported estimates of over 700 active groups in 2010.

Despite their increasing popularity, AFNs are still regarded by most customers as a complementary source of food provision, and they still represent a niche in the food market. Unfortunately, no data is available on their market share and turnover, rather AFNs are not even regarded in the national statistics on the market shares of the distribution channels. At the moment, it can be stated that AFNs are not even competing with mainstream distribution channels, as the quantity of food purchased by customers at these markets is too little.

\footnotetext{
${ }^{1}$ Data published by United States Department of Agriculture, retrieved at http://www.ams.usda.gov/localfood-directories/farmersmarkets on 03/05/2018

${ }^{2}$ National Farmers' Retail \& Markets Association

${ }^{3}$ National farmers' association, playing an important role in pushing the development of farmers' market through the Campagna Amica project. http://www.coldiretti.it
} 
The objective of this paper is to study the determinants of the quantity of food purchased by AFNs' customers through these channels, with respect to conventional markets. This will allow to identify the factors that can be used in the marketing strategy of AFNs to increase their importance in the food market.

To reach this objective, the paper is organized as follows. First, the research problem is framed within the relevant literature, to argue that an increase in the quantity of food purchased through AFNs may have a positive effect in terms of food system sustainability. Then, data from a survey involving 1200 Italian alternative food market shoppers are analyzed; the share of households' food provisions purchased through alternative markets is studied against a set of factors through an ordinal logistic regression model. Results are compared and discussed with respect to previous findings in the literature, while some potential trajectories of development of AFNs are suggested in the conclusions.

\section{Types of AFNs and sustainability potential}

The core features of different AFN models depend on their value proposition and the way it is put into a process of value creation and capture (Barth et al. 2017). The role of the AFN initiator is crucial to this respect, as it shapes all the ambition behind the initiative, including the organization pattern, the characteristics of the products on sale, and the type of relation established with the customers (Wubben et al. 2013). AFN business models may either be initiated by (i) individual farmers, (ii) collective associations of producers, or (iii) farmers and consumers together (Chiffoleau et al. 2016). In the first case, the farmer takes the initiative by selling directly to consumers at the farm or at open-air markets, or even by taking orders on the internet and delivering products to consumers at home (Chiffoleau et al. 2016). When collective associations of producers start the initiative, business models of AFN become more complex, resulting in farmers' markets, box schemes, or collective farmers' shops (Marino 2017). Other models of AFNs concern the joint efforts of producers and consumers, that may commit themselves to a mutual support, as in community-supported agriculture schemes (Blasi et al. 2015), or start a relation linked to the collective purchase of food products by groups of consumers, as in solidarity purchasing groups (Brunori et al., 2012; Cembalo 2015).

There are several reasons explaining the attraction that AFNs exert on consumers. One is that they believe that local products have a higher quality than products sold through mainstream channels (Wolf et al. 2005; Lyon et al. 2009), although the existence of this quality gap has not been conclusively demonstrated (Archer et al. 2003). Ethical and environmental reasons can also be important (Kneafsey et al. 2013), but the main value added of AFNs is often seen in the reconnection between producers and consumers (Hinrichs 2000; Renting et al. 2003; Mount 2012). Supporting the local economy is becoming a factor in food choices, and consumers are ready to pay extra for locally produced food. A survey conducted by Eurobarometer (2012) shows that $36 \%$ of European consumers may be willing to pay more for local food. Consumers from South Carolina (USA) have been found to be willing to pay an average premium up to $27 \%$ of the initial price for State-produced products (Carpio and IsengildinaMassa 2009); similar results are available for UK (Arnoult et al. 2007). 
Although the current literature on AFNs is now much less enthusiastic about their potential contribution to sustainability than it was in the early years of their emergence (Forssell and Lankoski 2014), the research supports the idea that shortening food supply chains results in a positive impact on a number of issues relevant for sustainability at the local level.

As for the environmental implications of alternative food markets, the initial claims that they may be able to reduce food miles and greenhouse gas emissions (Schonhart et al. 2009) have been countered by the evidence that AFNs are not by definition more environmentally friendly than conventional marketing channels (Edwards-Jones 2010). However, positive environmental impacts can be attained when AFNs have a high degree of localness, intended as identity, governance, or size (Schmitt et al. 2017).

The social value of AFNs is widely studied by the literature. The embeddedness of these marketing channels in the local community is often seen as their main benefit in terms of sustainability of the food system (Hinrichs 2000). Indeed, reconnecting consumers to the upstream stages of the supply chain may improve their knowledge and understanding of food and farming (Feagan and Morris 2009; Sage 2003) and encourage the consumption of fresher and more nutritious products (Lamine 2005), possibly leading to positive changes in the consumption patterns (Pascucci et al. 2011). The direct relation between producers and consumers may increase the level of trust between them, with a positive effect on the social capital of the whole community (Kneafsey et al. 2013; Cicatiello et al. 2015). As a result, AFNs "have capacity to 're-socialize' or 're-spatialize' food" (Kneafsey et al. 2013; p.29), thus improving the capacity of consumers to make value judgements about foods.

AFNs are also believed to carry a positive economic impact because they mostly involve small and medium-scale farms, which usually have difficult access to the conventional chains due to competitiveness problems and inconsistency in their supply (Schmitt et al. 2017). The relational governance typical of AFNs may offer to these farms the possibility to achieve a higher efficiency and a better market access, thus increasing their bargaining power (Carbone 2017). In this sense, building local food chains is a way to keep these farms in the market. Some studies also suggest that shortening supply chains helps retaining economic value within the local system (Ilbery and Maye 2005) through the so-called multiplier effect (Mundler and Laughrea 2016; Henneberry et al. 2009). It should also be remarked that the potential of these initiatives increases as they start sharing successful local experiences with other networks, thus activating a process of change at higher levels (Rossi 2017).

\section{Methodology}

\section{Methodology of the survey}

Consumers' approach to food purchase at alternative markets was investigated by means of data retrieved during a survey conducted in Italy in 2012. The survey was part of a larger research with the general aim of analyzing the environmental and economic impact of different forms of AFNs, such as farm shops, farmers' markets, solidarity purchasing groups (SPG), box schemes, and some early experiences of communitysupported agriculture (Blasi et al. 2015; Mastronardi et al. 2015; Marino 2017). The survey covered 45 cases of alternative markets located in, or nearby, 5 Italian cities, two in 
the North (Turin and Trento), two in the Center (Rome and Pisa), and one in the South (Lecce) of the country. Together with the geographical criterion, the selection of the cities considered the level of embeddedness of AFNs in the local context, by choosing places where AFN channels had been diffused for long time.

Convenience sampling was used to select respondents, who were all participants to different alternative food markets; they were recruited upon availability by asking if they agreed to answer to a questionnaire. No representativeness can be assured when convenience sampling is applied, but this technique is widely used in behavioral science research (Graveter and Forzano 2008), as it can provide a good overview of the phenomenon, especially when large samples are concerned.

Those who agreed to participate in the survey were asked to answer a structured questionnaire with 9 closed questions concerning the following issues:

- Demographic profile;

- Food shopping channels;

- Approach to AFNs (motivations, intensity of participation, etc.);

- Expenditure at alternative food markets;

- Perception of benefits of buying from alternative food markets.

The same questionnaire was administered to all consumers interviewed. Those shopping at farm shops and at farmers' markets were interviewed face-to-face after having completed their purchases. Instead, for consumers participating to SPG, box schemes, and CSA, that usually keep contacts with the organizers through emails, an online version of the questionnaire was used. The analysis here presented focuses on data about the share of food provisions that shoppers buy through different distribution channels (alternative vs. mainstream channels), together with some key features of their purchase (motivations, type of food, expenditure) and demographic variables.

Out of the 1200 consumers that completed the questionnaire, the 27 observations from the 3 CSA cases were excluded from the analysis, because they were not enough to support the study of possible differences in the shopping pattern with respect to other cases. Therefore, the final database used in the elaborations consisted of 1173 observations.

\section{Data description}

Data was first processed with Excel to attain a description of the sample based on sociodemographic and behavioral variables. More than one third of the sample was involved in a box scheme, and 58\% of respondents were participants of short food chains located around Rome, which was the largest city covered by the survey. Table 1

Table 1 AFN models covered by the survey and number of respondents

\begin{tabular}{lll}
\hline Market format & Number of cases & Number of respondents \\
\hline Farm shop & 16 & 243 \\
Farmers' market & 11 & 289 \\
SPG & 9 & 186 \\
Box scheme & 6 & 455 \\
Total & 42 & 1173 \\
\hline
\end{tabular}


summarizes the number of consumers interviewed, broken down by AFN models. All models were covered in the 5 cities where the survey took place, except for box scheme participants, who were only recruited in Rome, Pisa, and Turin.

The profile of the respondents was consistent with previous researches on AFN shoppers (Zepeda 2009; Wolf et al. 2005; Byker et al. 2012), showing a high level of education (58\% held a university degree), a prevalence of women (67\%), and an average age of 46 years old. The average household expenditure for food was $100 €$ per week, considering the food bought at all distribution channels.

The two main channels for respondents' food purchase were AFNs (44\% of total food purchases on average) and supermarkets (38\% on average), but the variability of the data was very high, as shown by the error bars in Fig. 1. Namely, the distribution of respondents per share of expenditure at AFNs showed two peaks, one around 10-20\% and another at 50\% (Fig. 2).

Among the products bought most often through AFNs, 87\% of respondents mentioned fruit and vegetables, while animal products, such as meat, eggs, and cheese, were reported by $59 \%$ of the sample. Less consumers declared to buy olive oil $(17 \%)$ and wine $(9 \%)$ through alternative markets.

\section{Logistic regression}

A logistic regression model was used to investigate the factors influencing the share of total food provisions purchased at alternative markets by consumers. Starting from the answers to the question, "Out of the total food products you buy, what is the share that you purchase through alternative markets?", which was expressed as a percentage, four classes were created to describe the distribution of respondents with respect to the share of food purchase at AFNs (Table 2):

1. Over $60 \%$ of food purchased through AFNs

2. $40-60 \%$ of food purchased through AFNs

3. $20-40 \%$ of food purchased through AFNs

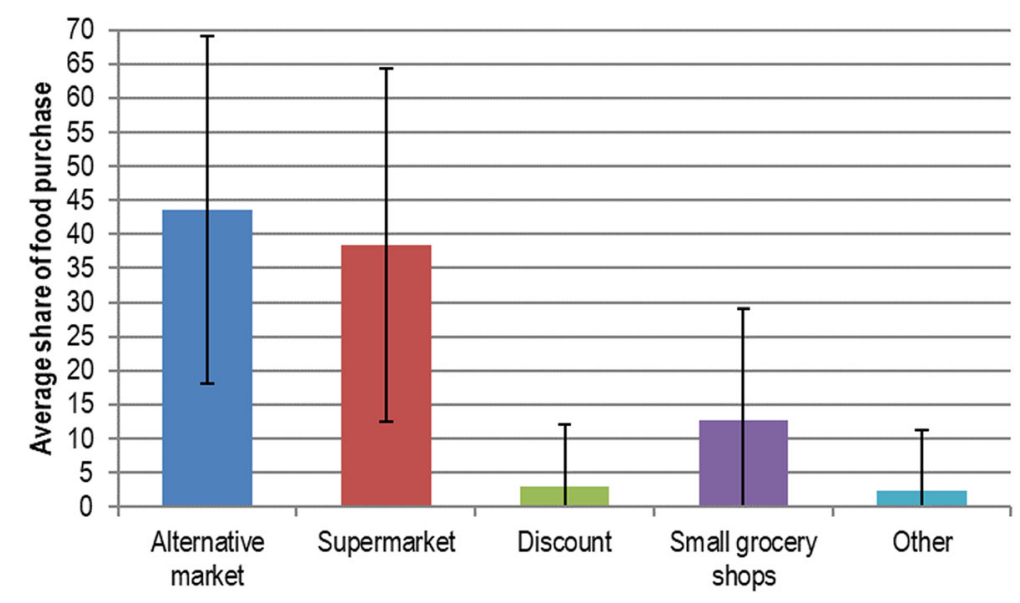

Fig. 1 Average share of food purchased in different marketing channels. Respondents were asked to estimate these shares with respect to the expenditure for food at each channel. After expressing a percentage for each channel, the interviewer verified that the total sum of the values expressed was equal to $100 \%$ 


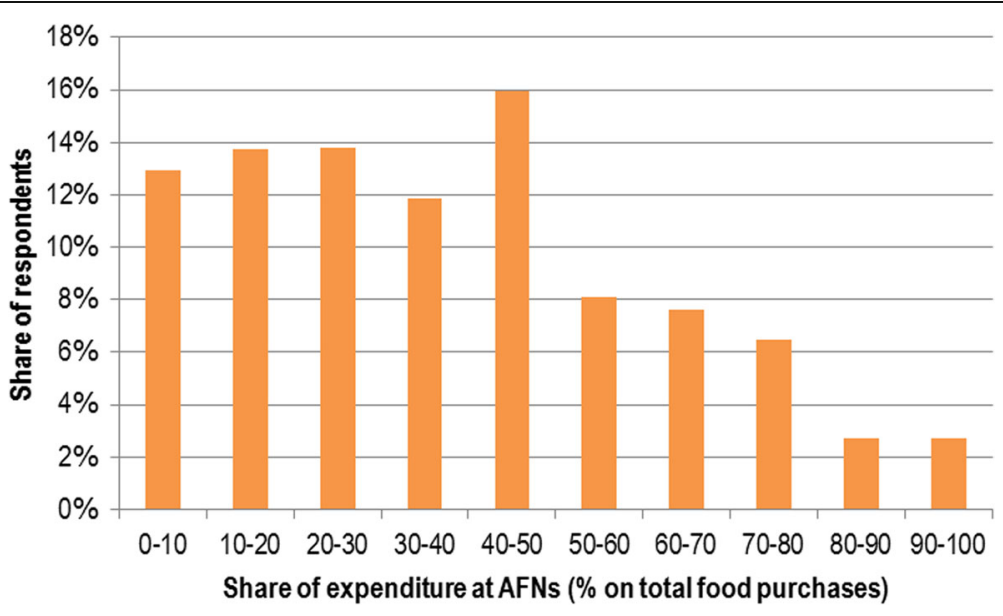

Fig. 2 Distribution of observations per share of expenditure at AFNs

4. Less than $20 \%$ of food purchased through AFNs

The resulting categorical variable was inputted as the dependent variable in an ordinal logit against a set of potential factors.

The choice of an ordinal instead of a multinomial logistic regression followed the construction of the dependent variable, which was intrinsically ordered from lower to higher classes of expenditure. Among the different ordinal logistic models available, a proportional odds model was selected to compare the probability of an equal or smaller response with respect to the explanatory factors (Hosmer Jr et al. 2013). Fourteen explanatory factors were inputted in the model (Table 3):

- Seven factors related to consumers' motivations to purchase food through AFNs, expressed with a 1-5 Likert scale

- The total weekly expenditure for food, expressed in euros and ranging from 25 to $300 €$

- A dummy variable related to the presence of children in the household

- A dummy variable to express whether respondents were aged over 50 years old

- Two dummy variables related to products that respondents usually buy (or do not buy) through AFNs

- A dummy variable describing whether respondents had been purchasing food at the alternative market where they were interviewed for more than 1 year

- A categorical variable describing the type of AFN

Table 2 Observations by class of expenditure at alternative markets

\begin{tabular}{llll}
\hline Class & Description of the class & Number of observations & \% of observations \\
\hline 1 & Over 60\% of food purchased through AFNs & 267 & 22.8 \\
2 & $40-60 \%$ of food purchased through AFNs & 292 & 24.9 \\
3 & $20-40 \%$ of food purchased through AFNs & 301 & 25.7 \\
4 & $0-20 \%$ of food purchased through AFNs & 313 & 26.6 \\
\hline
\end{tabular}


Table 3 Descriptive statistics of the factors

\begin{tabular}{|c|c|c|c|c|c|}
\hline \multicolumn{6}{|l|}{ Numerical variables } \\
\hline Variable & Unit & Min & Max & Mean & $\begin{array}{l}\text { Std. } \\
\text { Dev. }\end{array}$ \\
\hline Motivation: healthier products & $\begin{array}{l}\text { 1-5 Likert } \\
\text { scale }\end{array}$ & 1.000 & 5.000 & 4.801 & 0.532 \\
\hline Motivation: high-quality products & $\begin{array}{l}1-5 \text { Likert } \\
\text { scale }\end{array}$ & 1.000 & 5.000 & 4.754 & 0.567 \\
\hline Motivation: local products & $\begin{array}{l}\text { 1-5 Likert } \\
\text { scale }\end{array}$ & 1.000 & 5.000 & 4.498 & 0.827 \\
\hline $\begin{array}{l}\text { Motivation: environmentally } \\
\text { sustainable products }\end{array}$ & $\begin{array}{l}\text { 1-5 Likert } \\
\text { scale }\end{array}$ & 1.000 & 5.000 & 4.592 & 0.775 \\
\hline Motivation: economic saving & $\begin{array}{l}1-5 \text { Likert } \\
\text { scale }\end{array}$ & 1.000 & 5.000 & 3.069 & 1.271 \\
\hline Motivation: convenience & $\begin{array}{l}\text { 1-5 Likert } \\
\text { scale }\end{array}$ & 1.000 & 5.000 & 3.632 & 1.227 \\
\hline Motivation: trust in producers & $\begin{array}{l}\text { 1-5 Likert } \\
\text { scale }\end{array}$ & 1.000 & 5.000 & 4.367 & 0.805 \\
\hline $\begin{array}{l}\text { Household weekly expenditure } \\
\text { for food }\end{array}$ & Euros & 25.000 & 300.000 & 107.630 & 56.879 \\
\hline \multicolumn{6}{|l|}{ Categorical and dummy variables } \\
\hline Variable & Type & Categories & $\begin{array}{l}\text { Categories' } \\
\text { description }\end{array}$ & Observations & $\%$ \\
\hline \multirow[t]{2}{*}{ Children under 12 years old } & Dummy & 0 & No & 758 & $64.6 \%$ \\
\hline & & 1 & Yes & 415 & $35.4 \%$ \\
\hline \multirow[t]{2}{*}{ Aged over 50 years old } & Dummy & 0 & No & 751 & $64.0 \%$ \\
\hline & & 1 & Yes & 422 & $36.0 \%$ \\
\hline \multirow{2}{*}{$\begin{array}{l}\text { Products purchased: fresh fruit } \\
\text { and vegetables }\end{array}$} & Dummy & 0 & No & 150 & $12.8 \%$ \\
\hline & & 1 & Yes & 1023 & $87.2 \%$ \\
\hline \multirow{2}{*}{$\begin{array}{l}\text { Products purchased: animal } \\
\text { products }\end{array}$} & Dummy & 0 & No & 495 & $42.2 \%$ \\
\hline & & 1 & Yes & 678 & $57.8 \%$ \\
\hline \multirow{2}{*}{$\begin{array}{l}\text { Over } 1 \text { year participating in the } \\
\text { AFN }\end{array}$} & Dummy & 0 & No & 373 & $31.8 \%$ \\
\hline & & 1 & Yes & 800 & $68.2 \%$ \\
\hline \multirow[t]{4}{*}{ Type of market } & Categorical & FS & Farm shop & 243 & $20.7 \%$ \\
\hline & & FM & $\begin{array}{l}\text { Farmers' } \\
\text { market }\end{array}$ & 289 & $24.6 \%$ \\
\hline & & BOX & Box scheme & 455 & $38.8 \%$ \\
\hline & & SPG & $\begin{array}{l}\text { Solidarity purchasing } \\
\text { group }\end{array}$ & 186 & $15.9 \%$ \\
\hline
\end{tabular}

Other sociodemographic variables were excluded after controlling their insignificance in the model (education, gender, size of the household). Geographical variables (city or region) were also excluded given the uneven partition of box scheme participants across the survey areas.

The logistic regression showed an $R^{2}$ (Nagelkerke) of 0.184 . The likelihood ratio test, the score test, and the Wald test were all significant at $p<0.0001$. The parameters of the model express the expected probability of an observation to move from the reference category of the dependent variable $(0-20 \%$ of food expenditure at AFNs) to the subsequent classes of expenditure at AFNs, as a response to the changing values of the explanatory factors. Namely, the logit coefficients report the expected change of the 
response variable for a one-unit increase in the predictors, according to the log-odds scale, assuming the other variables in the model are held constant.

\section{Results and discussion}

Table 4 reports the parameters of the logistic regression model and their significance in explaining the share of food provisions purchased by respondents through AFNs.

Among consumers' motivations, the search for environmentally sustainable products is the most important factor in determining the probability of the observations to fall in the classes where the share of food purchased through alternative markets is higher. The relation is positive, showing that a greater importance of environmentally related motivations improves the probability of purchasing a meaningful quantity of food at AFNs. Previous literature reports that consumers participating in short food chains likely search for high-quality and environmentally sustainable products (Tregear 2011; Wolf et al. 2005; Lyon et al. 2009; Kneafsey et al. 2013; Seyfang 2006); here, results suggest that consumers for whom these issues are more important have a higher probability to use AFNs as a main channel for food provision.

The total amount of money spent by the household for food provisioning emerges as a very significant factor, slightly decreasing the probability to fall in the classes with higher expenditure at AFNs. Therefore, the higher the total expenditure for food by the household, the lower is the share of food purchased through alternative markets. This can be explained considering that families with higher expenditure for food are likely

Table 4 Parameters of the ordinal logistic regression

\begin{tabular}{|c|c|c|c|c|}
\hline Factors & Value & Std. error & Wald chi-square & $\operatorname{Pr}>\mathrm{Chi}^{2}$ \\
\hline Motivation: healthier products & +0.119 & 0.159 & 0.563 & 0.4529 \\
\hline Motivation: high-quality products & $+0.236^{*}$ & 0.140 & 2.851 & 0.0913 \\
\hline Motivation: local products & -0.069 & 0.074 & 0.852 & 0.3558 \\
\hline Motivation: environmentally sustainable products & $+0.342^{* * *}$ & 0.094 & 13.258 & 0.0003 \\
\hline Motivation: economic saving & -0.014 & 0.048 & 0.081 & 0.7759 \\
\hline Motivation: convenience & +0.084 & 0.052 & 2.567 & 0.1091 \\
\hline Motivation: trust in producers & +0.123 & 0.077 & 2.511 & 0.1131 \\
\hline Household weekly expenditure for food & $-0.004^{* * *}$ & 0.001 & 13.210 & 0.0003 \\
\hline Children under 12 years old -0 & 0.000 & 0.000 & & \\
\hline Children under 12 years old -1 & -0.035 & 0.129 & 0.074 & 0.7856 \\
\hline Aged over 50 years old -0 & 0.000 & 0.000 & & \\
\hline Aged over 50 years old -1 & -0.091 & 0.133 & 0.469 & 0.4936 \\
\hline Products purchased: animal products - 0 & 0.000 & 0.000 & & \\
\hline Products purchased: animal products - 1 & $+0.689^{* * *}$ & 0.112 & 37.920 & $<0.0001$ \\
\hline Products purchased: fresh fruit and vegetables - 0 & 0.000 & 0.000 & & \\
\hline Products purchased: fresh fruit and vegetables - 1 & $+0.690^{* * *}$ & 0.185 & 13.960 & 0.0002 \\
\hline Over 1 year participating in the AFN - 0 & 0.000 & 0.000 & & \\
\hline Over 1 year participating in the AFN - 1 & $+0.619^{* * *}$ & 0.122 & 25.522 & $<0.0001$ \\
\hline Type of market - FS & 0.000 & 0.000 & & \\
\hline Type of market - FM & +0.008 & 0.179 & 0.002 & 0.9646 \\
\hline Type of market - BOX & $+0.733^{* * *}$ & 0.179 & 16.827 & $<0.0001$ \\
\hline Type of market - SPG & +0.297 & 0.189 & 2.479 & 0.1154 \\
\hline
\end{tabular}


the larger ones, that have been found to be less involved in AFNs (Blasi et al. 2015). These families may have stricter economic constraints in food shopping, thus relying more on conventional distribution channels for their purchases and using alternative markets only for small amounts or specific types of food. Indeed, shopping at AFNs requires to bear an additional cost not (always) in terms of higher prices of the food products, but especially in terms of a more demanding organization and planning of the purchase (Cembalo et al. 2015).

Among the demographical factors, neither the presence of children in the household nor the age of respondents are significant in the model. Apparently, participants that use AFNs as a main channel do not show significant demographic differences with respect to the average AFN shopper, whose profile is rather constant among countries and business models (Wolf et al. 2005; Pascucci et al. 2011).

The two factors related to the type of products purchased are both significant in the model, with a positive effect on the quantity of food procured through AFNs. While no previous evidence to this regard is available for animal products, the result on fruit and vegetables is consistent with findings in the literature, reporting how these products are typically included in the basket of AFN shoppers (La Trobe 2001; Varner and Otto 2008).

Customers' loyalty to the market emerges as a very important factor in shaping the quantity of food purchased at AFNs. Respondents that have been shopping through AFNs for more than one year are much more likely to use these channels as a main source of food provision. This confirms previous evidences that establishing a strong relation with participants is crucial in alternative marketing channels (Chiffoleau 2009; Sage 2003). AFN participants have been found to have an orientation to planning food purchases and preparation (Cembalo et al. 2015), and establishing a long-term relation with AFNs may facilitate their food choices, resulting in a higher quantity of food purchased through these channels.

Results also highlight the influence that the different AFN business models exert on the quantity of food purchased. With respect to farm shops-which can be considered the first form of short food supply chain-respondents participating to box schemes show a higher probability to use AFNs as a main food source. Box schemes are organized along a weekly or monthly based delivery of a box containing local foods (Mastronardi et al. 2015), providing households with a permanent provision of food. Results suggest that this business model is very effective in convincing the households to buy a meaningful share of the total food they need, leaving other food channels as complementary sources of provisions. In this sense, box scheme can be considered the new frontier of AFNs driven by collective producers (Hashem et al. 2018; Aggestam et al. 2017).

Some limitations of the study shall be mentioned to complete the interpretation of results. First, in this study it was not possible to compare the results obtained from the sample of AFN shoppers with data gathered on customers of conventional distribution channels. However, if the aim is to study the conditions for AFNs to get out of their niche, it seems reasonable to investigate the choices of consumers who are already familiar with these channels. Indeed, the factors underlying their choice to use AFNs as a main food channel can be reflected in the behaviour of customers joining alternative markets in the future. Second, as the demographic profile of AFN shoppers is very well defined and stable, demographic variables could not contribute to the explanation of the share of expenditure at AFN; while this was somewhat expected, it could be 
interesting to analyze the dynamics of expenditure at alternative markets in segments of consumers with different demographic profile. Cembalo et al. (2015) compared SPG participants to a control group of consumers, finding that AFN customers show many rational traits of the average consumers, but with a higher sensitiveness on environmental issues and a greater involvement in food preparation and consumption. To this respect, AFNs show a potential of expansion linked to a better communication of the benefits of local food for the health, the environment, and the local community (Kumar and Smith 2018). At the same time, it cannot be denied that several barriers of access still exist for low-income consumers to join these alternative markets (Hodgins and Fraser 2018).

\section{Conclusions}

AFNs may contribute to improving the sustainability of food systems, which is now triggered by the intensification of production processes and by the standardization of food products all along the supply chain. AFNs can exert a positive impact on several aspects of sustainability in local food systems, and they are increasingly considered by consumers as possible sources of food provisioning. Consumers are pushed to these markets by the search of high-quality, healthy, and environmentally sustainable products, but the quantity of food marketed through AFNs still restricts them in a niche. This paper focuses on this "quantity dilemma", by studying the factors explaining the quantity of food-expressed as the share of food provisions, with respect to conventional distribution channels-purchased at alternative markets by AFN participants.

Results show that consumers' motivations play a key role in increasing the share of food purchased through AFNs, especially when such motivations deal with the quality of the products and their environmental value, which are key attributes for alternative food shoppers. Another key factor concerns customers' relation with alternative markets; whenever AFN business models are able to convey their core values to consumers, thus retaining them for long time, the share of food expenditure made at these markets raises. This confirms that one of the main advantages of AFNs lies in their capacity to foster the establishment of long-term relationships among members of the community that would otherwise not get in contact. In this sense, AFN business models that put a higher number of stakeholders in touch seem to have a greater potential to increase their market share. Another factor that emerges from the analysis is that different AFN business models show a different likelihood to sell customers a meaningful quantity of food; box schemes' participants are more likely to buy most of their food at AFNs with respect to consumers participating in other types of alternative markets.

Two main considerations can be drawn from the results of this study, both linked to possible strategies to foster the development of AFNs and, more specifically, to raise their importance as sources of food for consumers. First, it seems that there are already some segments of consumers who are ready to use AFNs as a main channel for food purchases; targeting these consumers in the marketing strategies of AFNs is therefore crucial to increase the market share of these experiences. Second, the business models that seem more interesting to achieve high shares of food expenditure by customers are those characterized by the core values of loyalty and collectivism. Not surprisingly, new forms of AFNs sharing these values are emerging as very attractive marketing channels for consumers. These business models shall be regarded as the future of alternative markets, as they may provide an effective contribution to increase the importance of these channels in the food systems. 
Abbreviations

AFN: Alternative food network; EU: European Union; UK: United Kingdom; USA: United States of America

\section{Acknowledgements}

Data have been collected during the project "Analisi e valutazione degli scenari connessi agli impatti producibili sul mercato e supporto alla definizione di indirizzi strategici per la promozione delle esternalità positive delle filiere corte", coordinated by the University Consortium for Socioeconomic and Environmental Research (CURSA). The author thanks the participants to the LV Convegno Studi SIDEA held in Perugia on 13-15th September 2018 for their useful comments on an earlier version of this manuscript.

\section{Author's contributions}

The author read and approved the final manuscript.

\section{Funding}

Italian Ministry of Agriculture, Food and Forestry, DM4369 of 24/02/2012.

\section{Availability of data and materials}

The datasets used and analysed during the current study are available from the author on reasonable request.

\section{Competing interests}

The authors declare no competing interests.

Received: 15 November 2018 Accepted: 11 May 2020

Published online: 29 May 2020

\section{References}

Aggestam V, Fleiß E, Posch A (2017) Scaling-up short food supply chains? A survey study on the drivers behind the intention of food producers. J Rural Stud 51:64-72

Archer GP, Sánchez JG, Vignali G, Chaillot A (2003) Latent consumers' attitude to farmers' markets in North West England. Br Food J 105(8):487-497

Arnoult, M., Lobb, A., and Tiffin, R. (2007) The UK consumer's attitudes to and willingness to pay for, imported foods. Contributed paper prepared for presentation at the 105th EAAE Seminar International Marketing and International trade of Quality Food Products', Bologna, Italy, March 8-10, 2007.

Aubry C, Kebir L (2013) Shortening food supply chains: a means for maintaining agriculture close to urban areas? The case of the French metropolitan area of Paris. Food Policy 41:85-93

Barth H, Ulvenblad PO, Ulvenblad P (2017) Towards a conceptual framework of sustainable business model innovation in the agri-food sector: a systematic literature review. Sustainability 9(9):1620

Blasi E, Cicatiello C, Pancino B, Franco S (2015) Alternative food chains as a way to embed mountain agriculture in the urban market: the case of Trentino. Agric Food Econ 3(1):3

Brunori G, Rossi A, Guidi F (2012) On the new social relations around and beyond food. Analysing consumers' role and action in Gruppi di Acquisto Solidale (Solidarity Purchasing Groups). Sociologia ruralis 52(1):1-30

Byker C, Shanks J, Misyak S, Serrano E (2012) Characterizing farmers' market shoppers: a literature review. J Hunger Environ Nutr 7(1):38-52

Carbone A (2017) Food supply chains: coordination governance and other shaping forces. Agric Food Econ 5(1):3

Carpio CE, Isengildina-Massa O (2009) Consumer willingness to pay for locally grown products: the case of South Carolina. Agribusiness: Int J 25(3):412-426

Cembalo L (2015) Innovation and valorization in supply chain network. Agric Food Econ 3(1):5

Cembalo L, Lombardi A, Pascucci S, Dentoni D, Migliore G, Verneau F, Schifani G (2015) "Rationally local": consumer participation in alternative food chains. Agribusiness 31(3):330-352

Cembalo L, Migliore G, Schifani G (2013) Sustainability and new models of consumption: The solidarity purchasing groups in Sicily. J Agric Environ Ethics 26(1):281-303

Chiffoleau Y (2009) From politics to co-operation: the dynamics of embeddedness in alternative food supply chains. Sociologia Ruralis 49(3):218-235

Chiffoleau Y, Millet-Amrani S, Canard A (2016) From short food supply chains to sustainable agriculture in urban food systems: food democracy as a vector of transition. Agriculture 6(4):57

Cicatiello C, Pancino B, Pascucci S, Franco S (2015) Relationship patterns in food purchase: observing social interactions in different shopping environments. J Agric Environ Ethics 28(1):21-42

Edwards-Jones G (2010) Does eating local food reduce the environmental impact of food production and enhance consumer health? Proceed Nutr Soc 69(04):582-591

Eurobarometer (2012) Europeans' attitudes towards food security, food quality and the countryside. Special Eurobarometer 389. Available at https://ec.europa.eu/commfrontoffice/publicopinion/archives/ebs/ebs_389_en.pdf. Accessed 30 July 2019

Feagan RB, Morris D (2009) Consumer quest for embeddedness: a case study of the Brantford Farmers' Market. Int J Consumer Stud 33(3):235-243

Forssell S, Lankoski L (2014) The sustainability promise of alternative food networks: an examination through "alternative" characteristics. Agric Hum Values. https://doi.org/10.1007/s10460-014-9516-4

Franco, S., Cicatiello, C., Blasi, E., \& Pancino, B. (2015). Le filiere corte auto-organizzate dai consumatori: il modello dei Gruppi di Acquisto Solidale. Economia Agro-alimentare/Food Economy n.2/2015.

Galli F, Bartolini F, Brunori G, Colombo L, Gava O, Grando S, Marescotti A (2015) Sustainability assessment of food supply chains: an application to local and global bread in Italy. Agric Food Econ 3(1):21

Goodman D (2003) The quality "turn" and alternative food channels: reflections and agenda. J Rural Stud 19(1):1-7 
Graveter FJ, Forzano LAB (2008) Research methods for the behavioural sciences. In: Cengage Learning EMEA, International Editions 3e. Gardners Books, UK

Hashem S, Migliore G, Schifani G, Schimmenti E, Padel S (2018) Motives for buying local, organic food through English box schemes. Br Food J 120(7):1600-1614

Henneberry SR, Whitacre BE, Agustini HN (2009) An evaluation of the economic impacts of Oklahoma farmers' markets. J Food Distrib Res 40(856-2016-57815):64

Higgins V, Dibden J, Cocklin C (2008) Building alternative food networks: certification, embeddedness and agri-environmental governance. J Rural Stud 24:15-27

Hinrichs CC (2000) Embeddedness and local food systems: notes on two types of direct agricultural markets. J Rural Stud 16(3):295-303

Hinrichs CC (2014) Transitions to sustainability: a change in thinking about food systems change? Agric Hum Values 31(1):143-155

Hodgins KJ, Fraser ED (2018) "We are a business, not a social service agency." Barriers to widening access for low-income shoppers in alternative food market spaces. Agric Hum Values 35(1):149-162

Hosmer DW Jr, Lemeshow S, Sturdivant RX (2013) Applied logistic regression (Vol. 398). Hoboken: Wiley

Ilbery B, Maye D (2005) Food supply chains and sustainability: evidence from specialist food producers in the Scottish/English borders. Land Use Policy 22(4):331-344

Kirwan J (2006) The interpersonal world of direct marketing: examining conventions of quality at UK farmers' markets. J Rural Stud 22(3):301-312

Kneafsey M, Venn L, Schmutz U, Trenchard L, Eyden-Wood T, Bos E, Sutton G, Blackett M (2013) Short food supply chains and local food systems in the EU. In: A state of play of their socio-economic characteristics. Publication of the European Commission Joint Research Centre, Luxembourg

Kumar A, Smith S (2018) Understanding local food consumers: theory of planned behavior and segmentation approach. J Food Products Market 24(2):196-215

La Trobe H (2001) Farmers' markets: consuming local rural produce. Int J Consumer Stud 25(3):181-192

Lamine C (2005) Settling shared uncertainties: local partnership between producers and consumers. Sociological Ruralis 45(4): 324-345

Lyon P, Collie V, Kvarnbrink E, Colquhoun A (2009) Shopping at the farmers' market: consumers and their perspectives. J Foodservice 20(1):21-30

Marino, D. (Ed.). (2017). Agricoltura urbana e filiere corte: un quadro della realtà italiana. FrancoAngeli.

Marsden T, Banks J, Bristow G (2000) Food supply chain approaches: exploring their role in rural development. Sociologia Ruralis 40(4):424-438

Mastronardi L, Marino D, Cavallo A, Giannelli A (2015) Exploring the role of farmers in short food supply chains: the case of Italy. Int Food Agribusiness Manage Rev 18(1030-2016-83060):109-130.

Mount P (2012) Growing local food: scale and local food systems governance. Agric Hum Values 29(1):107-121

Mundler P, Laughrea S (2016) The contributions of short food supply chains to territorial development: a study of three Quebec territories. J Rural Stud 45:218-229

Pascucci S, Cicatiello C, Franco S, Pancino B, Marino D (2011) Back to the future? Understanding change in food habits of farmers' market customers. Int Food Agribusiness Manage Rev 14(4):105-126

Renting H, Marsden TK, Banks J (2003) Understanding alternative food networks: exploring the role of short food supply chains in rural development. Environ Plann A 35(3):393-412

Rossi A (2017) Beyond food provisioning: the transformative potential of grassroots innovation around food. Agriculture 7(1):6

Sage C (2003) Social embeddedness and relations of regard: alternative 'good food' networks in south-west Ireland. J Rural Stud 19(1):47-60

Schmitt E, Galli F, Menozzi D, Maye D, Touzard JM, Marescotti A et al (2017) Comparing the sustainability of local and global food products in Europe. J Cleaner Production 165:346-359

Schonhart M, Penker M, Schmid E (2009) Sustainable local food production and consumption. Challenges for implementation and research. Outlook Agric 38(2):175-182

Seyfang G (2006) Ecological citizenship and sustainable consumption: examining local organic food networks. J Rural Stud 22(4):383-395

Tregear A (2011) Progressing knowledge in alternative and local food networks: critical reflections and a research agenda. J Rural Stud 27(4):419-430

Van Der Ploeg JD (2010) The food crisis, industrialized farming and the imperial regime. J Agrarian Change 10(1):98-106

Varner T, Otto D (2008) Factors affecting sales at farmers' markets: an lowa study. Rev Agric Econ 30(1):176-189

Wolf MM, Spittler A, Ahern J (2005) A profile of farmers' market consumers and the perceived advantages of produce sold at farmers' markets. J Food Distrib Res 36(1):192-201

Wubben EFM, Fondse M, Pascucci S (2013) The importance of stakeholder-initiatives for business models in short food supply chains: the case of the Netherlands. J Chain Netw Sci 13(2):139-149

Xia T (2009) Asymmetric price transmission, market power, and supply and demand curvature. J Agric Food Ind Organ 7(1):1-25.

Zepeda L (2009) Which little piggy goes to market? Characteristics of US farmers' market shoppers. Int J Consumer Stud 33(3):250-257

\section{Publisher's Note}

Springer Nature remains neutral with regard to jurisdictional claims in published maps and institutional affiliations. 